\title{
HUBUNGAN ANTARA PENGAWASAN, PROSEDUR KERJA DAN KONDISI FISIK DENGAN TERJADINYA KECELAKAAN KERJA PADA PERAWAT DI RUANG RAWAT INAP RUMAH SAKITPERMATA BUNDA MEDAN TAHUN 2017
}

\author{
Nur Azizah', Setiawan ${ }^{2}$, Gerry Silaban ${ }^{2}$ \\ ${ }^{1}$ Alumni Program Studi S2 Ilmu Kesehatan Masyarakat USU \\ ${ }^{2}$ Staf Pengajar Fakultas Kesehatan Masyarakat USU \\ Email :dr_ziaaja@yahoo.co.id ${ }^{1}$, \\ setia-06@hotmail.com², gerry_silaban@usu.ac.id ${ }^{3}$
}

\begin{abstract}
A hospital is one of the work places which potentially causes danger to its employees. The cases which commonly occur are pricked by hypodermic needles, sprained, lumbago, and the other infections. A survey conducted a the beginning of 2017 revealed that there were some cases of occupational accident undergone by nurses at Permata Bunda Hospital such as HNP (Hernias Nukleus Pulposus), pricked by hypodermic needles, scratched by ampoule lids, and slipped. Methods: The objective of the research was to analyze the correlation of supervision, work procedure, and physical condition with the incidence of occupational accident in nurses in the inpatient wards of Permata Bunda Hospital, Medan. The data were analyzed by using chi square test. The samples were 96 nurse practitioners as the respondents, taken by using consecutive sampling technique. Results and Discussion: The result of the research showed that $17.7 \%$ of the respondents had undergone occupational accidents such as HNP (14.6\%), pricked by hypodermic needles (15.6\%), and slipped (10.4\%). The result of chi square statistic test showed that the three variables: supervision $(p=0.000)$, work procedure $(p=0.005)$, and physical condition $(p=0.000)$ had significant correlation with nurses' occupational accidents. Conclusion: It is recommended that the hospital management increase occupational safety and health for the nurses by providing training about the danger of occupational accident in nurses and about occupational safety and health.
\end{abstract}

Keywords: Supervision, Work Procedure, Physical Condition, Occupational Accident

\section{PENDAHULUAN}

Rumah sakit adalah sebuah industri jasa tempat penyediaan layanan kesehatan untuk masyarakat. Rumah sakit merupakan salah satu tempat kerja yang berpotensi menimbulkan bahaya. Rumah sakit di Amerika Serikat mencatat rata-rata 6,8 cedera atau kecelakaan yang berhubungan dengan pekerjaan dan penyakit untuk setiap 100 karyawan penuh pada tahun 2011 (OSHA, 2013). Kasus yang sering terjadi adalah tertusuk jarum, terkilir, sakit pinggang, tergores, luka bakar dan penyakit infeksi lainnya. Di Australia, pada 813 perawat, $87 \%$ pernah mengalami low backpain (Sholihah, 2013). Di Indonesia, penelitian dari Joseph tahun 2005-2007 mencatat bahwa angka kecelakaan needle stick 
injury atau tertusuk jarum mencapai 38$73 \%$ dari total petugas kesehatan (Idayanti, 2008). Kasus kecelakaan kerja yang terjadi maka berdasarkan UndangUndang No. 36 Tahun 2009 tentang Kesehatan Pasal 165, pengelola tempat kerja di rumah sakit mempunyai kewajiban untuk menjaga keselamatan para pekerja yaitu dengan menerapkan keselamatan dan kesehatan kerja di rumah sakit.

Penelitian terhadap perawat perinatologi di RSUD Tugurejo Semarang, dalam satu tahun terakhir perawat mengalami kecelakaan kerja (tertusuk jarum) tertinggi 14 kali (Kurniawati, 2013). Penelitian yang dilakukan oleh Sarastuti pada Tahun 2016 menunjukkan bahwa klasifikasi kecelakaan kerja menurut jenis cedera paling banyak kontak dengan benda tajam dan kasar, seperti kontak dengan jarum, pisau, dan benda tajam sejenisnya yaitu sebanyak 16 kasus $(69,6 \%)$. Secara spesifik, kecelakaan kerja di RS UGM sebagian besar berupa kontak dengan jarum atau tertusuk jarum (needle stick injuries) yang dapat menyebabkan transmisi penularan darah dan cairan tubuh (bloodborne pathogen) (Sarastuti, 2016).
Kecelakaan kerja pada perawat dianggap sebagai suatu masalah serius karena mengancam kesehatan dan kesejahteraan pasien dan petugas kesehatan secara global (Maria, 2015). Kecelakaan tersebut yang pada akhirnya dapat mempengaruhi produktivitas kerja perawat. Produktivitas kerja yang rendah pada akhirnya berdampak terhadap pelayanan kesehatan yang diberikan oleh rumah sakit. Laporan Bureau Labor Statistics USA cedera yang sering terjadi rumah sakit antara lain terpeleset (slip), tersandung (trip) dan terjatuh (fall) (STF) adalah 38,2 per 10.000 karyawan, yang berakibat hari kerja hilang, produktivitas berkurang, klaim kompensasi yang mahal dan kemampuan berkurang dalam merawat pasien (NIOSH, 2010).

Kecelakaan kerja di kalangan petugas kesehatan dan non kesehatan kesehatan di Indonesia belum terekam dengan baik. Sebagai faktor penyebab, sering terjadi karena kurangnya kesadaran pekerja dan kualitas serta keterampilan pekerja yang kurang memadai. Menurut International Labour Organitation (ILO) setiap tahun sebanyak dua juta pekerja meninggal dunia karena kecelakaan kerja yang disebabkan oleh faktor kelelahan. 
Penelitian tersebut dijelaskan dari 58.115 sampel, 18.828 diantaranya $(32,8 \%)$ mengalami kelelahan (Sedarmayanti, 2011).

Rumah Sakit Permata Bunda merupakan salah satu rumah sakit kelas B yang berada di Kota Medan dan merupakan salah satu rumah sakit rujukan dari rumah sakit kabupaten. Rumah Sakit Permata Bunda memiliki 126 tempat tidur inap, yang tersedia rata-rata 80 tempat tidur inap. Sumber daya manusia rumah Sakit Permata Bunda terdiri dari 132 tenaga medis mayoritas yaitu dokter spesialis sebanyak 97 orang, dokter sub spesialis 22 orang, dokter umum 10 orang dan dokter umum perusahaan 3 orang. Tenaga keperawatan sebanyak 195 orang, mayoritas Akper sebanyak 76 orang, SPK sebanyak 7 orang dan sarjana keperawatan sebanyak 48 orang.

Berdasarkan data kecelakaan kerja di Rumah Sakit Permata Bunda kasus kecelakaan kerja pada Bulan Mei 2017 perawat banyak ditemukan seperti HNP (Hernia Nukleus Pulposus), tertusuk jarum, tergores tutup ampul, terpeleset. Data kasus kecelakaan kerja tersebut antara lain di ruangan Berlian Prima ada 5 orang, di ruangan berlian eksekutif sebanyak 8 orang, di ruangan kelas utama A dan B (VIP) sebanyak 5 orang, di ruangan Zamrud tidak ditemukan kasus kecelakaan kerja, di ruangan Topaz sebanyak 5 orang yang mengalami kecelakaan kerja dan pada ruangan Delima sebanyak 5 orang dan hanya pada ruangan Delima yang ditemukan kasus perawat yang terpelesat.

Kecelakaan kerja pada perawat ini menimbulkan kerugian bagi perawat itu sendiri maupun pihak rumah sakit. Tingginya kasus kecelakaan kerja perawat di Rumah Sakit Permata Bunda juga berakibat pada terganggunya proses pelayanan kesehatan di rumah sakit, oleh karena itu perlu diketahui faktor risiko penyebab kecelakaan tersebut sehingga dapat dilakukan upaya pencegahan. Berdasarkan latar belakang tersebut membuat penulis tertarik untuk meneliti tentang hubungan antara pengawasan, prosedur kerja dan kondisi fisik dengan terjadinya kecelakaan kerja pada perawat di ruang rawat inap di Rumah Sakit Permata Bunda Medan Tahun 2017.

\section{METODE PENELITIAN}

Penelitian ini merupakan penelitian kuantitatif dengan menggunakan metode deskriptif korelasional yaitu Penelitian ini 
dilakukan di RS Permata Bunda, dengan

pertimbangan karena didapatkan kasus

kecelakaan kerja pada perawat setiap bulannya. Populasi adalah seluruh perawat di ruang rawat inap dewasa di Rumah Sakit Permata Bunda. Jumlah sampel dalam penelitian ini dalam penelitian ini sampel sebanyak 96 orang.

Analisis data dengan uji chi square. Teknik pengambilan sampel dalam penelitian ini adalah consecutive sampling dengan jumlah sampel sebanyak 96 perawat pelaksana.

HASIL DAN PEMBAHASAN Analisis Univariat

Tabel 1. Karakteristik Responden

\begin{tabular}{|c|c|c|}
\hline \multirow{2}{*}{$\begin{array}{l}\text { Karakteristik } \\
\text { Usia }\end{array}$} & $\mathrm{n}$ & $\%$ \\
\hline & & \\
\hline $\begin{array}{l}24-45 \text { tahun } \\
\text { (Dewasa) }\end{array}$ & 91 & 94,8 \\
\hline 46-55 tahun (Pra & 5 & 5,2 \\
\hline Lanjut Usia) & & \\
\hline Jenis Kelamin & & \\
\hline laki-laki & 27 & 28,1 \\
\hline Perempuan & 69 & 71,9 \\
\hline Status Pernikahan & & \\
\hline belum menikah & 26 & 27,1 \\
\hline Menikah & 70 & 72,9 \\
\hline Pendidikan & & \\
\hline SPK & 2 & 2,1 \\
\hline D3 keparawatan & 67 & 69,8 \\
\hline S1-Keperawatan & 24 & 25,0 \\
\hline S2 Keperawatan & 3 & 3,1 \\
\hline Jumlah & 96 & 100,0 \\
\hline
\end{tabular}

\section{Analisis Bivariat}

Tabel 2. Chi Square

\begin{tabular}{|c|c|c|c|c|c|c|c|}
\hline \multirow{3}{*}{ Responden } & \multicolumn{4}{|c|}{ Kecelakaan Kerja } & \multirow{2}{*}{\multicolumn{2}{|c|}{ Jumlah }} & \multirow{3}{*}{$p$. } \\
\hline & \multicolumn{2}{|c|}{ Tidak } & \multicolumn{2}{|r|}{ Ya } & & & \\
\hline & n & $\%$ & n & $\%$ & $\mathbf{n}$ & $\%$ & \\
\hline \multicolumn{8}{|l|}{ Pengawasan } \\
\hline Cukup Baik & 0 & 0,0 & 6 & 100,0 & 6 & 100,0 & \multirow{2}{*}{0,000} \\
\hline Baik & 70 & 87,8 & 11 & 12,2 & 90 & 100,0 & \\
\hline \multicolumn{8}{|c|}{ Prosedur Kerja } \\
\hline Kurang Baik & 0 & 0,0 & 1 & 100,0 & 1 & 100,0 & \multirow[t]{3}{*}{0,005} \\
\hline Cukup Baik & 7 & 53,8 & 5 & 41,7 & 12 & 100,0 & \\
\hline Baik & 72 & 86,7 & 11 & 13,3 & 83 & 100,0 & \\
\hline \multicolumn{8}{|l|}{ Kondisi Fisik } \\
\hline Kurang Baik & 2 & 50,0 & 2 & 50,0 & 4 & 100,0 & \multirow[t]{3}{*}{0,000} \\
\hline Cukup Baik & 6 & 37,5 & 10 & 62,4 & 16 & 100,0 & \\
\hline Baik & 71 & 93,4 & 5 & 6,6 & 76 & 100,0 & \\
\hline
\end{tabular}

Uji bivariat dengan menggunakan uji chi square menunjukkan bahwa nilai $\mathrm{p}=0,000<0,05$ yang artinya ada hubungan yang signifikan antara pengawasan dengan kecelakaan perawat di ruang rawat inap Rumah Sakit Permata Bunda. Hasil uji bivariat dengan menggunakan uji Chisquare menunjukkan bahwa nilai $\mathrm{p}=0,005<0,05$ yang artinya ada hubungan yang signifikan antara prosedur kerja dengan kecelakaan perawat di ruang rawat inap Rumah Sakit Permata Bunda. Hasil uji bivariat dengan menggunakan uji Chi-square menunjukkan bahwa nilai $\mathrm{p}=0,000<0,05$ yang artinya ada hubungan yang signifikan antara kondisi fisik dengan kecelakaan perawat di ruang rawat ianap Rumah Sakit Permata Bunda. 


\section{Hubungan Pengawasan Hubungan Pengawasan dengan Kecelakaan Kerja Perawat di Ruang Rawat Inap Rumah Sakit Permata Bunda}

Berdasarkan hasil penelitian yang didapat, terbanyak perawat menyatakan pengawasan baik dari kepala perawat sebesar 93,7\%. Pengawasan yang dilakukan antara lain yaitu sebelum melakukan pergantian shift dilakukan pengarahan terlebih dahulu, pengawasan juga dilakukan pada saat perawat memberikan pelayanan kepada pasien, pengawasan kinerja berdasarkan SOP dan juga pengawasan terhadap posisi pada saat bekerja melayani pasien.

Penilaian hubungan antara pengawasan dengan kecelakaan kerja perawat di ruang rawat inap Rumah Sakit Permata Bunda menunjukkan bahwa nilai $\mathrm{p}=0,000<0,05$ yang artinya ada hubungan yang signifikan antara pengawasan dengan kecelakaan perawat di ruang rawat inap Rumah Sakit Permata Bunda. Hasil penelitian ini sesuai dengan penelitian yang dilakukan oleh Anshari (2016) yang menyatakan terdapat hubungan yang bermakna antara Pengawasan dengan kecelakaan kerja. di PT. Kunango Jantan Tahun 2016. Penelitian yang dilakukan oleh Harpeni (2015) juga menyatakan hal yang sama bahwa terdapat hubungan antara pengawasan dengan kecelakaan kerja pada pekerja bagian produksi PT Lutvindo Wijaya Perkasa Pekanbaru.

\section{Hubungan Prosedur Kerja dengan Kecelakaan Kerja Perawat di Ruang Rawat Inap Rumah Sakit Permata Bunda}

Prosedur kerja merupakan rangkaian langkah yang dilaksanakan untuk menyelesaikan kegiatan atau aktivitas, sehingga dapat tercapai tujuan yang diharapkan secara efektif dan efisien serta dapat dengan mudah menyelesaikan suatu masalah yang terperinci menurut waktu yang telah ditetapkan. Perawat juga memiliki prosedur kerja yang sudah ditetapkan dimana prosedur tersebut digunakan untuk melindungi perawat dan juga melindungi pasien.

Penilaian hubungan antara prosedur kerja dengan kecelakaan perawat di ruang rawat inap Rumah Sakit Permata Bunda menunjukkan nilai $\mathrm{p}=0,010<0,05$ yang artinya ada hubungan yang signifikan antara prosedur kerja dengan kecelakaan perawat di ruang rawat inap Rumah Sakit Permata Bunda.

Penelitian ini sesuai dengan penelitian yang dilakukan oleh Siregar (2014) yang menyatakan bahwa ada hubungan prosedur kerja dengan 
kecelakaan di PT Aqua Golden

Missisippi Bekasi dimana semakin tidak patuh pekerja dengan prosedur kerja maka akan semakin tinggi risiko kecelakaan kerja dan begitu juga sebaliknya semakin patuh pekerja maka akan semakin rendah risiko kecelakaan kerja. Kemudian berdasarkan hasil penelitian yang dilakukan oleh Putri (2017) menyatakan bahwa praktik penerapan SOP berhubungan dengan risiko kecelakaan kerjadi PT. X Tangerang.

Berdasarkan hasil penjabaran wawancara dan hasil observasi atas prosedur kerja, terhadap kepala ruangan bahwa hampir semua perawat yang bertugas selalu melakukan pekerjaan atau tindakan sesuai dengan standar yang diterapkan. Beberapa perawat yang terlupa atau tidak sesuai dengan prosedur dalam melakukan tindakan mungkin disebabkan karena buru-buru atau sedang dalam kondisi yang tidak sehat. Kepala perawat menyatakan bahwa seorang perawat harus memiliki sikap yang baik seperti mengikuti prosedur kerja dan harus peduli terhadap bahaya yang ada dirumah sakit, karena perawat tidak hanya bertanggung jawab terhadap keselamatannya sendiri tetapi yang terutama itu harus memperhatikan keselamatan pasien juga karena jika mereka bersikap yang buruk hal ini menyangkut mutu pelayanan rumah sakit juga. Tetapi masih adanya perawat yang bersikap kurang sesuai, seperti masih ada perawat yang tidak memakai sarung tangan saat menyuntik yang mungkin karena agar lebih gampang pada saat akan melakukan tindakan.

Prosedur Kerja K3 di rumah sakit digunakan untuk melindungi perawat. Pada dasarnya perawat di Rumah Sakit Permata Bunda sudah mengetahui tujuan dan manfaat jika mereka menerapkan prosedur kerja dengan baik, seperti mengurangi kesalahan atau kegagalan dalam proses kerja. Namun, beberapa dari perawat masih ada yang belum memiliki kesadaran untuk menerapkan prosedur kerja dalam melakukan pekerjaannya karena belum ada sanksi yang tegas, hanya berupa teguran saja, ada juga pekerja merasa terbebani dengan beberapa prosedur kerja, dan ada juga menyatakan prosedur kerja membuat pekerjaan merela lebih lambat. Penelitian ini ketidakpatuhan perawat terhadap peosedur kerja merupakan salah satu bentuk perbuatan tidak aman. Prakteknya perbuatan tidak aman pada perawat antara lain pada saat setelah menyuntik pasien, jarum suntik 
ditutup kembali dengan cara menutup langsung nal dengan menggunakan tangan, tidak menggunakan sarung tangan, tidak menggunakan sepatu safety, dan posisi salah saat bekerja. Perilaku tidak aman perawat saat bekerja tanpa menggunakan alat peindung diri sesuai dengan standart dapat mengakbatkan kecelakaan kerja dan menimbulkan penyakit akibat kerja.

Peningkatan kepatuhan perawat dalam melaksakan prosedur kerja dapat dilakukan dengan cara meningkatan kesadaran perawat untuk bertindak aman dalam upaya meningkatkan keselamatan dan kesehatan saat bekerja. Kesadaran perawat dapat ditumbuhkan dengan cara pelatihan-pelatihan guna meningkatkan pengetahuan perawat mengenai keselamatan dan kesehatan kerja dan juga pengetahuan mengenai bahaya kerja pada perawat sehingga perawat secara mandiri dapat berperilaku aman saat bekerja.

\section{Hubungan Kondisi Fisik dengan Kecelakaan Kerja Perawat di Ruang Rawat Inap Rumah Sakit Permata Bunda}

Kondisi fisik yang tidak prima dapat mengurangi kapasitas kerja dan ketahanan tubuh pekerja. Penurunan konsisi fisik pada perawat ditandai dengan ditandai dengan berkurangnya kemauan untuk bekerja yang sebabnya adalah persyaratan psikis. Penyebab kelelahan umum adalah monotoni, intensitas, dan lamanya kerja mental dan fisik, keadaan lingkungan. Para perawat pelaksana di Rumah Sakit Permata Bunda menyatakan sering mengantuk pada saat bekerja terkhusunya pada shift malam, ada juga yang menyatakan jantung berdebar akibat kelelahan pada saat bekerja, beberapa perawat juga mengeluh mengalami sakit punggung sehingga menggangu proses bekerja karena keluhan tersebut.

Penilaian hubungan antara kondisi fisik perawat dengan kecelakaan perawat di ruang rawat inap Rumah Sakit Permata Bunda menunjukkan nilai $\mathrm{p}=0,000<0,05$ yang artinya ada hubungan yang signifikan antara kondisi fisik dengan kecelakaan perawat di ruang rawat ianap Rumah Sakit Permata Bunda. Hasil penelitian ini sesuai dengan penelitian yang dilakukan oleh Sandewa (2014) menyatakan ada hubungan antara kondisi fisik dengan resiko kecelakaan kerja pada perawat diruang rawat inap RSUD Labuang Baji Makassar. Penelitian yang dilakukan oleh Hastuti (2017) juga menunjukkan bahwa terdapat hubungan antara kelelahan kerja dengan kejadian kecelakaan kerja pada pekerja bagian 
lambung di sebuah perusahaan konstruksi Semarang.

Hasil observasi atas kondisi fisik, banyak disimpulkan bahwa banyaknya pasien, jam kerja dan kondisi lingkungan yang mengakibatkan kondisi fisik mereka terganggu. Pasien-pasien di ruangan sering memanggil perawat seperti meminta agar pasien mengganti cairan, infus, pasien yang mengeluh kesakitan dan cenderung

marah-marah terhadap perawat, sehingga perawat cepat lelah hingga stress dan sakit kepala apabila sering di panggil-panggil dan bolak-balik ke ruangan rawat inap pasien. Jam kerja yang cenderung lama pun membuat mereka jadi bosan dalam bekerja dan mudah mengantuk dan terkadang kondisi lingkungan kerja yang kurang baik. Lemahnya kondisi fisik perawat menyebabkan perawat kurang berkonsentrasi dalam mengerjaan tugas dan tanggung jawabnya dan terkadang lalai dalam mengerjakan tugas tersebut yang dapat meningkatkan risiko terjadinya kecelakaan kerja.

Kecelakaan kerja juga timbul sebagai hasil gabungan dari beberapa faktor. Faktor yang paling utama adalah faktor perlatan teknis, lingkungan kerja, dan pekerja itu sendiri (Ridley, 2008).
Kecelakaan kerja pada perawat juga terjadi karena lingkungan kerja yang buruk seperti Memperpanjang waktu kerja berlebih ataupun beban kerja yang berlebih dan tidak disertai efesiensi yang tinggi, biasanya terlihat penurunan produktivitas serta kecenderungan untuk timbulnya kelelahan pada perawat. Kelelahan kerja akan menurunkan kinerja dan menambah tingkat kesalahan kerja. meningkatnya kesalahan kerja akan memberikan peluang terjadinya kecelakaan kerja.

\section{KESIMPULAN}

1. Jumlah Kecelakaan kerja perawat di ruang rawat inap Rumah Sakit Permata Bunda selama 2 bulan terakhir yang mengalami kecelakaan kerja sebesar mengalami kejadian kecelakaan kerja sebesar 17,7\% dari 96 perawat pelaksana.

2. Ada hubungan yang signifikan antara pengawasan dengan kecelakaan kerja perawat di ruang rawat inap Rumah Sakit Permata Bunda.

3. Ada hubungan yang signifikan antara prosedur kerja dengan kecelakaan kerja perawat di ruang rawat inap Rumah Sakit Permata Bunda. 
4. Ada hubungan yang signifikan antara kondisi fisik dengan kecelakaan kerja perawat di ruang rawat inap Rumah Sakit Permata Bunda.

\section{SARAN}

Berdasarkan hasil penelitian hubungan antara pengawasan, prosedur kerja dan kondisi fisik dengan terjadinya kecelakaan kerja pada perawat di ruang rawat inap Rumah Sakit Permata Bunda Medan, maka penulis menyarankan beberapa hal sebagai berikut:

1. Bagi Rumah Sakit Permata Bunda

a. Disarankan agar pihak manajemen Rumah Sakit Permata Bunda dapat meningkatkan upaya pengawasan, karena berdasarkan hasil penelitian pengawasan penggunaan safety shoes dan pengawasan posisi kerja perawat masih kurang diperhatikan. Oleh katena itu diharapakan Rumah Sakit Permata Bunda dapat melakukan pelatihan keselamatan dan kesehatan kerja kepada perawat terkhusunya mengenai penggunaan APD dan ergonomi. b. Pihak manajemen rumah sakit juga harus dapat meningkatkan fasilitas beristirahat yang baik bagi para perawat guna mencegah terjadinya kelelahan serta menghilangkan rasa lelah perawat sehabis bekerja.

2. Bagi Perawat

a. Kepala perawat diharapkan sebagai pelaksana aktif dalam mengawasi perawat dengan cara melakukan pengarahan setiap terjadi pergantaian jam kerja, mengingatkan perawat jika mereka melakukan kesalahan, memotivasi perawat untuk bertindak aman dan menciptakan lingkungan kerja yang aman dan nyaman sehingga dpata meningkatkan derajat kesehatan perawat.

b. Perawat diharapkan untuk meningkatkan kesadaran diri untuk dapat berperilaku aman seperti mengikuti prosedur kerja yang ditetapkan, menggunakan APD, dan melaporkan setiap kecelakaan kerja untuk selanjutnya dapat dievaluasi agar kejadian kecelakaan kerja tidak terulang kembali 
c. Perawat agar meningkatkan derajat kesehatan kerja dengan memanfaatkan

waktu istirahat sebaik mungkin sehingga tidak menggangu kondisi fisik dan dapat fokus melaksakan segala tugas dan tanggungjawab sebagai perawat.

\section{DAFTAR PUSTAKA}

Anshari, L. (2017) Faktor-faktor yang Berhubungan dengan Kecelakaan Kerja pada Karyawan PT Kunanggo Jantan Kota Padang Tahun 2016. Prosiding Seminar Nasional IKAKESMADA "Peran Tenaga Kesehatan dalam Pelaksanaan SDGs"

Harrianto, R. (2010). Buku Ajar Kesehatan Kerja. Jakarta: EGC

NIOSH. (2010). Slip, Trip And Fall Prevention For Healthcare Workers. Atlanta: Centers for Disease Control and Prevention

OHSA. (2013). Caring for Our Caregivers-Facts about Hospital Worker Safety. USA. Departement of Labour. Amerika.

Parlagutan, M.T, Pratama, M.Y. (2017). Hubungan Work Family Conflict Dengan Stres Kerja pada Perawat Wanita di Rumah Sakit Putri Hijau Medan. Jurnal Riset Hesti Medan Akper Kesdam I/BB Medan. Vol. 1, No.1 (2016), Tanggal Akses 10 Juni 2017.

Putri, F. A, (2017). Hubungan antara Pengetahuan, Praktik Penerapan SOP, Praktik Penggunaan APD dan Komitmen Pekerja dengan Risiko Kecelakaan Kerja di PT X Tangerang. Bagian Keselamatan dan Kesehatan Kerja, Fakultas

Kesehatan Masyarakat Universitas Diponegoro.

Ridley, J. (2008). Kesehatan dan Keselamatan Kerja. Jakarta : Penerbit Airlangga

Sandewa, S. (2014). Hubungan Perilaku dengan Resiko Kecelakaan Kerja pada Perawat di Ruang Rawat Inap RSUD Labuang Baji Makassar. STIKES Nani Hasanuddin Makassar

Sarastuti, D. (2016). Analisis Kecelakaan Kerja di Rumah Sakit Universitas Gajah Mada. Yogyakarta: Publikasi Ilmiah Faklutas Ilmu Kesehatan UGM

Sedarmayanti. (2011). Tata Kerja dan Produktivitas Kerja. Bandung : Mandar Maju

Sholihah, Q, Djohan AJ, (2013). K3 RSMeminimalisasi Kecelakaan dan Penyakit Akibat Kerja di Rumah Sakit. Malang. Universitas Brawijaya Press. 